\title{
A POINT-OF-CARE IMMUNOTEST FOR BEDSIDE DETERMINATION OF HEART-TYPE FATTY ACID- BINDING PROTEIN
}

Citation for published version (APA):

Tong, C-Y., Chan, C. P-Y., Cheung, K., Cautherley, G. W. H., Glatz, J. F. C., \& Renneberg, R. (2010). A POINT-OF-CARE IMMUNOTEST FOR BEDSIDE DETERMINATION OF HEART-TYPE FATTY ACIDBINDING PROTEIN. Analytical Letters, 43(4), 735-744. https://doi.org/10.1080/00032710903406987

Document status and date:

Published: 01/01/2010

DOI:

10.1080/00032710903406987

Document Version:

Publisher's PDF, also known as Version of record

Document license:

Taverne

Please check the document version of this publication:

- A submitted manuscript is the version of the article upon submission and before peer-review. There can be important differences between the submitted version and the official published version of record.

People interested in the research are advised to contact the author for the final version of the publication, or visit the DOI to the publisher's website.

- The final author version and the galley proof are versions of the publication after peer review.

- The final published version features the final layout of the paper including the volume, issue and page numbers.

Link to publication

\footnotetext{
General rights rights.

- You may freely distribute the URL identifying the publication in the public portal. please follow below link for the End User Agreement:

www.umlib.nl/taverne-license

Take down policy

If you believe that this document breaches copyright please contact us at:

repository@maastrichtuniversity.nl

providing details and we will investigate your claim.
}

Copyright and moral rights for the publications made accessible in the public portal are retained by the authors and/or other copyright owners and it is a condition of accessing publications that users recognise and abide by the legal requirements associated with these

- Users may download and print one copy of any publication from the public portal for the purpose of private study or research.

- You may not further distribute the material or use it for any profit-making activity or commercial gain

If the publication is distributed under the terms of Article $25 \mathrm{fa}$ of the Dutch Copyright Act, indicated by the "Taverne" license above, 


\section{A Point-of-Care Immunotest for Bedside Determination of Heart-Type Fatty Acid-Binding Protein}

\section{Chao-Yang Tong , Cangel Pui-Yee Chan, Kwan-Yee Cheung, George W. H.}

Cautherley , Jan F. C. Glatz \& Reinhard Renneberg

To cite this article: Chao-Yang Tong, Cangel Pui-Yee Chan , Kwan-Yee Cheung, George W. H. Cautherley, Jan F. C. Glatz \& Reinhard Renneberg (2010) A Point-of-Care Immunotest for Bedside Determination of Heart-Type Fatty Acid-Binding Protein, Analytical Letters, 43:4, 735-744, DOI: 10.1080/00032710903406987

To link to this article: https://doi.org/10.1080/00032710903406987

\section{Published online: 08 Feb 2010.}

Submit your article to this journal

山 Article views: 44

Q View related articles ¿

Citing articles: 1 View citing articles $ऍ$ 


\title{
Bioanalytical
}

\section{A POINT-OF-CARE IMMUNOTEST FOR BEDSIDE DETERMINATION OF HEART-TYPE FATTY ACID-BINDING PROTEIN}

\author{
Chao-Yang Tong, ${ }^{1}$ Cangel Pui-Yee Chan, ${ }^{2}$ \\ Kwan-Yee Cheung, ${ }^{3}$ George W. H. Cautherley, ${ }^{3}$ \\ Jan F. C. Glatz, ${ }^{4}$ and Reinhard Renneberg ${ }^{2}$ \\ ${ }^{1}$ Department of Emergency, Zhongshan Hospital of Fudan University, China \\ ${ }^{2}$ Department of Chemistry, The Hong Kong University of Science and \\ Technology, Hong Kong \\ ${ }^{3} R \& C$ Biogenius Limited, Hong Kong \\ ${ }^{4}$ Department of Molecular Genetics, Cardiovascular Research Institute \\ Maastricht, Maastricht University, The Netherlands
}

Heart-type fatty acid-binding protein (H-FABP) is a small cytosolic protein abundant in heart muscle cells. It offers great potential as a sensitive biomarker for early diagnosis of acute myocardial infarction (AMI).

Ninety-one patients presented to the Emergency Department suspected of AMI with a median symptom onset of $6 \mathrm{~h}$ (IQR 3-20h), of which $75(82.4 \%)$ had AMI. The diagnostic performance of a point-of-care immunotest for $\mathrm{H}-\mathrm{FABP}$ was compared with those of cardiac troponin $T$ (cTnT), creatinine kinase $M B$ (CK-MB), and myoglobin. The H-FABP immunotest was found to have a significant better sensitivity than the other markers and a better specificity than myoglobin and CK-MB. The H-FABP Immunotest gave the greatest area under the receiver operating characteristic (ROC) curve (0.864) for those admitted within $6 \mathrm{~h}$ after the onset of symptoms; whereas, cTnT gave the greatest area under the ROC curve (0.936) for those admitted 6-24 h. The H-FABP was also found to be the most efficient marker to diagnose patients suspected of AMI without ST-elevation and with a negative cTnT.

Early detection of $\mathrm{H}-\mathrm{FABP}$ using the point-of-care immunotest in patients suspected of AMI may allow more accurate targeting of appropriate therapy and considerable cost savings than the current diagnostic tests.

Keywords: Acute myocardial infarction; Bedside; Cardiac troponin T; Creatine kinase MB; Heart-type fatty acid-binding protein; Myoglobin; Point-of-care

Received 27 March 2009; accepted 3 August 2009.

Address correspondence to Reinhard Renneberg, Ph.D., Department of Chemistry, The Hong Kong University of Science and Technology, Clear Water Bay, Kowloon, Hong Kong. E-mail: chrenneb@, ust.hk or Chao-Yang Tong, M.D., Department of Emergency, Zhongshan Hospital of Fudan University, P. R. China. E-mail: tong.chaoyang@zs-hospital.sh.cn 


\section{INTRODUCTION}

Early and correct diagnosis of acute myocardial infarction (AMI) patients, enabling interventions to reduce the mortality rate, is of paramount importance. It is also important to identify patients who are not suffering from AMI and who can be sent home safely shortly after admission, thus contributing considerable economic gains for both patients and hospitals. Heart-type fatty acid binding protein $(\mathrm{H}-\mathrm{FABP})$ is a small cytosolic protein that is abundant in cardiac tissue. After myocardial ischemic damage, H-FABP can be detected in the blood as early as within $1 \mathrm{~h}$ after onset of chest pain, with peak values reached at 3-6h and plasma levels returning to normal within 24-30 h (Chan, Sanderson et al. 2004). The combination of initial H-FABP release after symptom onset, rapid kidney clearance from the circulation, and high cardiac specificity makes it as an early cardiac marker for the diagnosis of AMI (Chan, Sanderson et al. 2004; Ghani et al. 2000; Glatz, Van der Voort, and Hermens 2002; Nakata 2003). The H-FABP can also be used to detect perioperative AMIs and detect re-infarction if it occurs within $10 \mathrm{~h}$ after symptom onset (Chan, Sanderson et al. 2004; Fransen et al. 2000). Furthermore, it can permit an estimation of myocardial infarct size providing important prognosis information and identify patients who are susceptible to reperfusion strategies and distinguish patients who reperfuse their infarct-related artery from those who do not, as early as 30 min after starting thrombolytic treatment (Pelsers, Hermens, and Glatz 2005; Alhadi and Fox 2004; De Groot, Muijtjens, and Simoons 2001).

A one-step H-FABP immunotest is designed for detection of H-FABP in whole blood samples (Chan et al. 2003; Chan et al. 2003a; Chan et al. 2005; Chan et al. 2006; Leung et al. 2005). The test result is available within $15 \mathrm{~min}$ after addition of blood samples. It requires no sample pretreatment and, thus, can be applied in emergency situations. Combined with the well-established markers, troponins, it may allow more accurate targeting of appropriate therapy and considerable cost savings than the current diagnostic tests, i.e., ECG, troponins, myoglobin, and creatine kinase $\mathrm{MB}(\mathrm{CK}-\mathrm{MB})$ tests.

The aim of the present study was to evaluate the diagnostic performance of the H-FABP immunotest in patients presenting with chest pain and suspected of myocardial infarction compared to myoglobin, CK-MB, and cardiac troponin $\mathrm{T}(\mathrm{cTnT})$.

\section{METHODS}

\section{Participants}

Patients presenting to an Emergency Department (ED) were consecutively screened for entry criteria: onset of acute chest pain lasting for at least 20 min within the last $24 \mathrm{~h}$ and an age $>18$ years. A total of 91 patients met these entry criteria (Figure 1).

Blood samples were taken from every patient at hospital presentation together with routine blood sampling. The medical staffs were trained in performing and reading the H-FABP immunotest. They were blinded to the standard diagnosis. At presentation, current symptoms and past medical history were documented using a pre-defined protocol. Chronic renal failure (CRF) and pre-test physical exercise are 


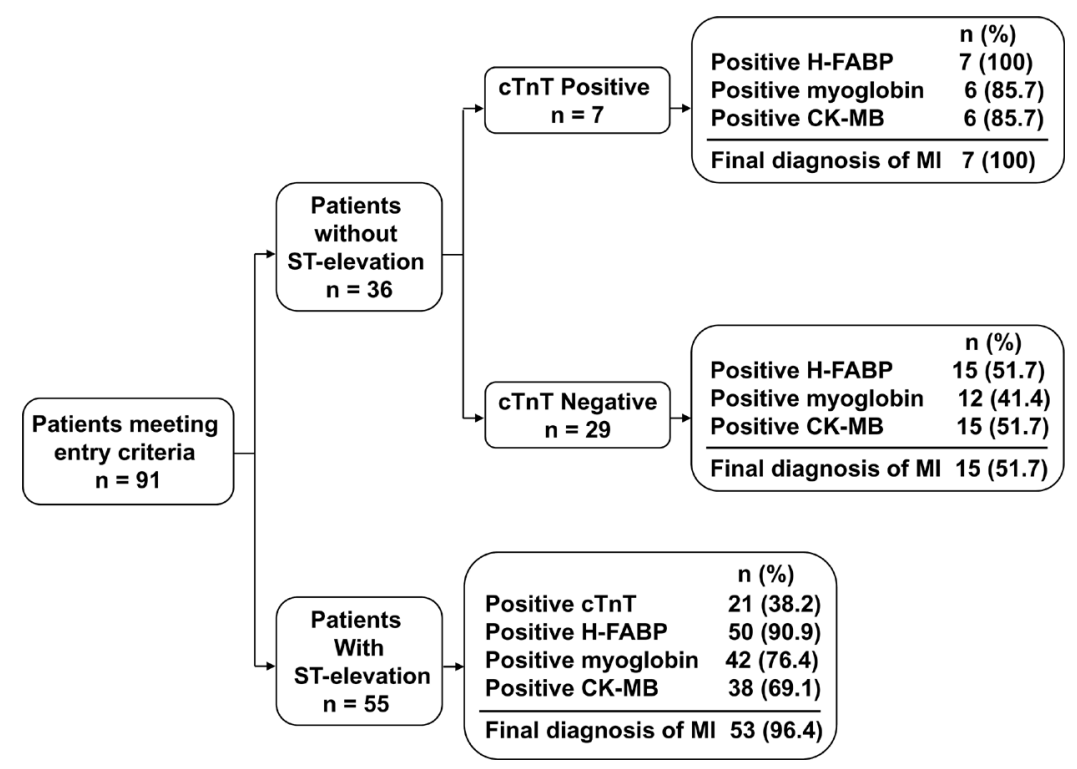

Figure 1. Flow chart of the study population.

known to cause elevated H-FABP levels; the presence of these conditions was excluded (Gorski, Hermens, and Borawski 1997; Yuan et al. 2003). Patients with no history of renal failure and serum creatinine level $<1.3 \mathrm{mg} / \mathrm{dL}$ were defined as having normal renal function. Follow-up information regarding standard diagnosis and outcome was extracted from medical notes and discharge letters.

\section{Cardiac Markers}

All patients underwent blood testing in the ED. Measurements of cTnT and myoglobin were conducted by using the Roche Diagnostics Elecsys ${ }^{\circledR} 2010$ instrument with the Troponin T STAT and Myoglobin STAT assay kits. The CK-MB levels were measured by immunoinhibition using a Johnson \& Johnson Vitros 950 analyzer. The cut-off values for cTnT and myoglobin were set up at $0.1 \mu \mathrm{g} / \mathrm{L}$ and $70 \mu \mathrm{g} / \mathrm{L}$, respectively. The CK-MB was considered to be positive when above $4 \mu \mathrm{g} / \mathrm{L}$. All patients were also tested with the H-FABP immunotest $\left(\right.$ CardioDetect ${ }^{\circledR}$, rennesens $\mathrm{GmbH}$, Berlin, Germany). It is a rapid chromatographic immunoassay designed for qualitative determination of H-FABP in blood samples with a cut-off value of $7 \mu \mathrm{g} / \mathrm{L}$. The test required $100-120 \mu \mathrm{L}$ of sample, and the result was interpreted within $15 \mathrm{~min}$ after sample application. The test result was positive if two red lines were visible (one at the area of the test zone and one at the control zone). This indicated that the concentration of H-FABP in the sample was above the threshold value of $7 \mu \mathrm{g} / \mathrm{L}$ and that an AMI had occurred. The result was negative if only one red line was visible at the control zone. This reading indicated that the concentration of H-FABP in the sample was below the threshold value and that an AMI had not occurred. The test was invalid if no line was visible or if a line only at the test zone was visible. In such a case, the measurement was repeated immediately. 


\section{Standard Diagnosis}

The standard diagnostic protocol included 12-lead ECG and cardiac markers (i.e., myoglobin, CKMB, and cTnT) (Domanovits, Schillinger, and Paulis 2002). The diagnosis was made after critical review of the clinical picture and all relevant information. Diagnostic outcome was categorized into three groups by a senior cardiologist according to the Joint Guidelines of the European Society of Cardiology and American College of Cardiology Committee: (i) ST-elevation myocardial infarction (STEMI); (ii) non-ST-elevation myocardial infarction (NSTEMI); and (iii) non-MI (Alpert, Thygesen, and Antman 2000).

\section{Statistics}

Data are presented as medians, interquartile ranges (IQR), means \pm standard deviation (SD), or 95\% confidence intervals (95\% CI). Diagnostic test criteria including sensitivity, specificity, negative and positive predictive values, and likelihood ratios were calculated by using MedCalc version 7.0 (MedCalc Software, Mariakerke, Belgium). The McNemar test was used to assess whether H-FABP or cTnT was positive earlier. The level of significance was set at $p<0.05$.

\section{RESULTS}

Between September 1, 2006 and May 24, 2007, a total of 91 patients were enrolled in this study (Figure 1). Mean age was 66.1 \pm 14.1 years (range: 21-96 years), and $76(84 \%)$ were male. Median time from symptom onset to first blood sample was $6 \mathrm{~h}$ (IQR 3-20 h). Patient characteristics are presented in Table 1. Forty-six patients $(51 \%)$ presented to the hospital within $6 \mathrm{~h}$ after the symptom onset and $33(36 \%)$ had prior history of cardiovascular event. Chest pain was considered typical in $87 \%$ of patients.

Acute myocardial infarction was diagnosed in $75(82 \%)$ individuals, of whom $53(58 \%)$ had STEMI and $22(24 \%)$ had NSTEMI. The non-MI group consisted of 16 patients with a final diagnosis of other coronary heart diseases or non-coronary heart diseases.

Table 1. Patient characteristics at presentation

\begin{tabular}{lcccc}
\hline & $\begin{array}{c}\text { Total } \\
(\mathrm{n}=91)\end{array}$ & $\begin{array}{c}\text { STEMI } \\
(\mathrm{n}=53)\end{array}$ & $\begin{array}{c}\text { NSTEMI } \\
(\mathrm{n}=22)\end{array}$ & $\begin{array}{c}\text { No MI } \\
(\mathrm{n}=16)\end{array}$ \\
\hline $\begin{array}{l}\text { Demographics } \\
\quad \text { Males, n (\%) }\end{array}$ & $76(84)$ & $46(87)$ & $19(86)$ & $11(69)$ \\
$\quad$ Age (years) & $66.1 \pm 14.1$ & $64.8 \pm 11.9$ & $70.9 \pm 13.2$ & $63.9 \pm 20.2$ \\
$\quad \begin{array}{l}\text { 65 years, n (\%) } \\
\text { Time from symptom onset, n (\%) }\end{array}$ & $48(53)$ & $27(51)$ & $14(64)$ & $7(44)$ \\
$\quad$ 6 h & $46(51)$ & $25(47)$ & $13(59)$ & $8(50)$ \\
$\quad$-24h & $45(49)$ & $28(53)$ & $9(41)$ & $8(50)$ \\
Prior history of cardiovascular event, n $(\%)$ & $33(36)$ & $12(23)$ & $13(59)$ & $8(50)$ \\
\hline
\end{tabular}

STEMI: ST-elevation myocardial infarction; NSTEMI: non-ST-evaluation myocardial infarction; MI: myocardial infarction. 


\section{Diagnostic Performance of the H-FABP Immunotest in the Whole Population}

The diagnostic performances of different cardiac markers are summarized in Table 2. The H-FABP immunotest was found to have a significant better sensitivity than all the other cardiac markers and a better specificity than myoglobin and CK-MB. The H-FABP immunotest was found to have a significant better diagnostic accuracy than the other cardiac markers, not only in the whole population, but also among the prespecified subgroups, including patients presenting less than $6 \mathrm{~h}$ after symptom onset, those presenting between 6-24 h after symptom onset, and those with a negative cTnT together with no ST-elevation.

\section{Patients Presenting with ST-Elevation on the Initial ECG}

The vast majority of patients (53 out of 55) presenting with ST-elevation on the first ECG had a final diagnosis of myocardial infarction (96.4\%). Of interest, these patients frequently had a more positive H-FABP than a positive cTnT $(94.3 \%$ vs. $79.2 \%, \mathrm{p}<0.05)$.

\section{Patients Without ST-Elevation on the Initial ECG and with a Negative cTnT}

Among the 22 NSTEMI patients, only 18 patients gave a positive cTnT, but 20 patients gave a positive H-FABP. A total of 19 out of 36 patients $(52.8 \%)$ without ST-elevation (29 out of 36) on the presenting ECG had a negative cTnT. In this subgroup of patients, $36.8 \%$ ( 7 out of 19) had a final diagnosis of myocardial infarction, of which $71.4 \%$ (5 out of 7 ) were found to have a positive H-FABP. Compared to myoglobin and CK-MB, H-FABP gave the highest diagnostic accuracy in this subgroup (Table 2).

\section{ROC Curves for Different Cardiac Markers}

The receiver operating characteristic (ROC) curves for H-FABP, myoglobin, CK-MB, and cTnT are shown in Table 3. The areas under the ROC curves (AUC) for diagnosis of AMI were 0.884 (95\% CI: $0.800-0.942)$ for H-FABP, 0.816 (95\% CI: 0.721-0.890) for myoglobin, 0.772 (95\% CI: $0.668-0.856$ ) for CK-MB, and 0.805 (95\% CI: 0.709-0.881) for cTnT. The overall AUC for H-FABP was significantly greater than those of the other cardiac markers. The H-FABP test also gave the greatest AUC [0.864 (95\% CI: 0.731-0.947)] for those patients admitted to the hospital within $6 \mathrm{~h}$ after the onset of symptoms; whereas, cTnT gave the greatest AUC [0.936 (95\% CI: 0.820-0.986)] for those patients admitted to the hospital 6-24 h after the onset of symptoms. Thus, H-FABP has a great potential as an excellent cardiac marker for diagnosis of AMI in the early phase. Furthermore, it gave the greatest AUC [0.774 (95\% CI: 0.527-0.929)] when compared to myoglobin [0.655 (95\% CI: 0.406-0.853)] and CK-MB [0.679 (95\% CI: 0.429-0.870)] for those patients without ST-elevation on the initial ECG and with a negative cTnT. 


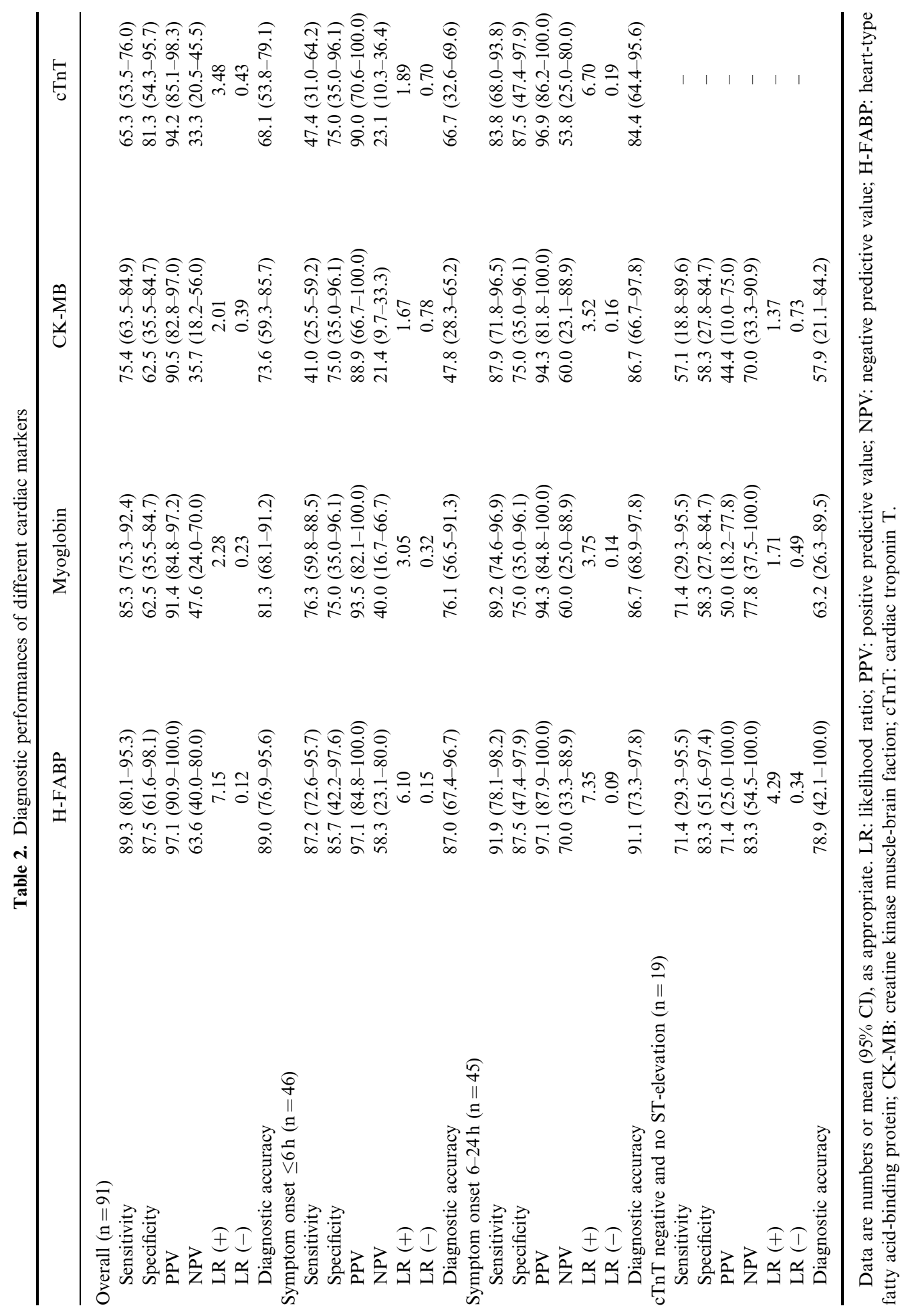




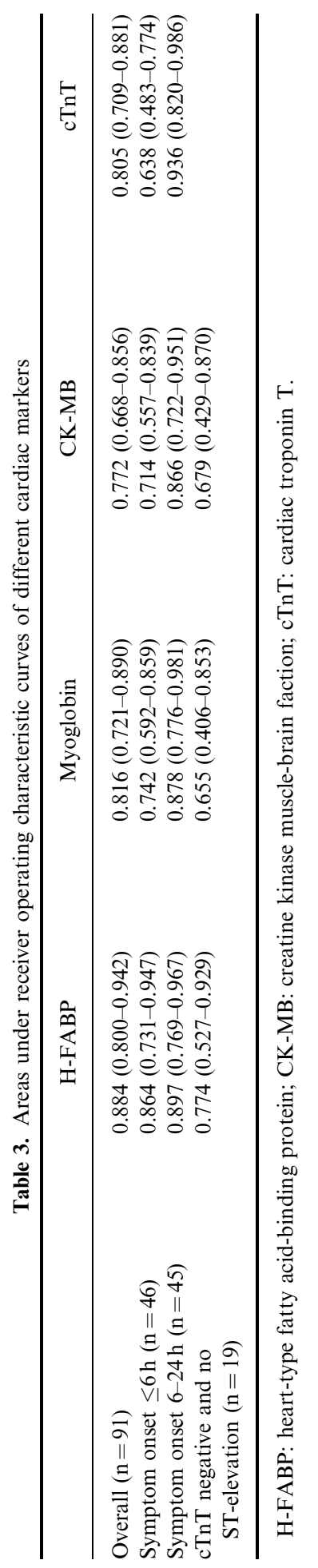

741 


\section{DISCUSSION}

Early detection of H-FABP using CardioDetect ${ }^{\circledR}$ in patients suspected of AMI gave the best diagnostic performance compared with conventional cardiac markers, especially in those patients admitted to the hospital within the first $6 \mathrm{~h}$ after the onset of symptoms.

The small molecular weight of H-FABP $(15 \mathrm{kDa})$ favors its early release, due to the higher permeability of the endothelial barrier for small proteins. These characteristics, along with a low physiological concentration for the identification of myocardial damage, enable H-FABP to have an improved diagnostic capability when compared with other early cardiac markers, e.g., myoglobin. The myocardial content of H-FABP $(0.57 \mathrm{mg} / \mathrm{g}$ wet weight $)$ is four- to five-fold lower than that of myoglobin $(2.7 \mathrm{mg} / \mathrm{g}$ wet weight), yet the plasma reference concentration of $\mathrm{H}-\mathrm{FABP}(1.8 \mu \mathrm{g} / \mathrm{L})$ is 19 -fold lower than that of myoglobin $(34 \mu \mathrm{g} / \mathrm{L})$. This means that after injury the tissue to plasma gradient is almost five-fold steeper for H-FABP than for myoglobin, making plasma H-FABP rise above its upper reference concentration at an earlier point after AMI onset, thus permitting an earlier diagnosis of AMI (Glatz, Haastrup, and Hermens 2002, Okamoto et al. 2000). In the EUROCARDI multi-center study, patients admitted 0-3 hours after onset of symptoms showed the AUC of 0.845 for FABP and of 0.717 for myoglobin, while patients admitted 3-6 hours after onset of symptoms showed areas of 0.945 for FABP and 0.892 for myoglobin, indicating that FABP was an earlier marker than myoglobin (Glatz, Haastrup, and Hermens 1997). As a result, FABP has a markedly higher sensitivity than that of myoglobin at an earlier stage for detection of myocardial infarction. Chan et al. demonstrated that H-FABP reliably diagnosed AMI patients $1 \mathrm{~h}$ after admission and $100 \%$ of non-AMI patients were excluded with no false negative results (Chan, Sanderson et al. 2004). The late markers cTnI and creatine kinase (CK) have the similar diagnostic performance only 7 hours later. Nakata also reported that H-FABP gave the greatest diagnostic and prognostic powers when compared to myoglobin, cTnT, and CK-MB within $12 \mathrm{~h}$ after the onset of symptoms (Nakata 2003).

The diagnostic performance of CardioDetect ${ }^{\circledR}$ that we reported is similar to that of in-hospital patients suspected of AMI and patients with acute ischemic chest pain delivered by a mobile intensive care unit (MICU) (Alhashemi 2006; Ecollan et al. 2007). The use of the CardioDetect ${ }^{\circledR}$ appears to be of unique value in the early stage of AMI. Indeed, the specificity of the CardioDetect ${ }^{\circledR}$ in our study and the previous studies was found to be similar to that of repeated troponins measurements but with a much greater sensitivity in the first $6 \mathrm{~h}$ of AMI.

The appropriate handling of patients with suspected AMI depends on the availability of results from simple, sensitive, and specific diagnostic tests. In patients with typical early ECG changes of ST-segment elevation, the diagnosis of AMI is easily and rapidly established. However, at least $40 \%$ of patients with AMI show no diagnostic ECG changes on admission. Also, in approximately 60 to $70 \%$ of patients admitted to the hospital because of chest pain, the suspicion of AMI will ultimately be dismissed because of lack of diagnostic ECG changes and negative biochemical tests. In this study, H-FABP was found to be the most efficient cardiac marker to diagnose NSTEMI in patients suspected of AMI without ST-elevation on the initial ECG and negative troponin. Previous studies also demonstrated that 
the CardioDetect ${ }^{\circledR}$ may be particularly valuable to manage patients with atypical symptoms or silent MI or in those with non-contributive ECG and in whom the need for urgent reperfusion is uncertain (Alhashemi 2006; Ecollan et al. 2007).

\section{LIMITATIONS}

The H-FABP immunotest may be elevated in patients with renal deficiency owing to the impaired performance of their kidneys. This may lead to a false-positive test result. Also, in patients with angina pectoris, a false-positive result cannot be excluded. A small amount of H-FABP is present in skeletal muscle. Therefore, false-positive results are technically possible for athletes and for individuals who have exercised vigorously prior to the testing.

This study is based at a single center. Therefore, the generalizability of our findings to other settings requires further study. Second, this is a hospital based rather than community based study, and so the application of our findings to the family physician or outpatient clinic setting is unclear.

\section{CONCLUSION}

The performance of H-FABP demonstrates that the test has a role as an early marker but is less meaningful as a late marker, due to its rapid clearance. Therefore, samples should be obtained as soon as possible after the onset of symptoms to maximize its clinical utility. As the therapeutic window for AMI is within the first 6 hours and an earlier intervention has a better success rate, the availability of an early rapid test is important. In order to decrease the risk of falsely excluded patients with ongoing AMI, a combined measurement of two cardiac markers, an early one such as H-FABP and a later marker such as troponins may provide the optimum diagnostic performance.

\section{REFERENCES}

Alhadi, H. A., and K. A. Fox. 2004. Do we need additional markers of myocyte necrosis: The potential value of heart fatty-acid-binding protein. QJM 97: 187-198.

Alhashemi, J. A. 2006. Diagnostic accuracy of a bedside qualitative immuno-chromatographic test for acute myocardial infarction. Am. J. Emerg. Med. 24: 149-155.

Alpert, J. S., K. Thygesen, and E. Antman. 2000. Myocardial infarction redefined-a consensus document of The Joint European Society of Cardiology/American College of Cardiology Committee for the redefinition of myocardial infarction. J. Am. Coll. Cardiol. 36: 959-969.

Chan, C. P., K. W. Sum, K. Y. Cheung, J. F. Glatz, J. E. Sanderson, A. Hempel, M. Lehmann, I. Renneberg, and R. Renneberg. 2003. Development of a quantitative lateral-flow assay for rapid detection of fatty acid-binding protein. J. Immunol. Methods 279: 91-100.

Chan, C. P., W. S. Cheng, J. F. Glatz, D. Van Der Voort, J. E. Sanderson, A. Hempel, M. Lehmann, I. Renneberg, and R. Renneberg. 2003a. Early diagnosis of acute myocardial infraction using immunosensors and immunotests. Anal. Lett. 36: 1987-2004. 
Chan, C. P., J. E. Sanderson, J. F. Glatz, W. S. Cheng, A. Hempel, and R. Renneberg. 2004. A superior early myocardial infarction marker. Human heart-type fatty acid-binding protein. Z. Kardiol. 93: 388-397.

Chan, C. P., T. S. Wan, K. L. Watkins, M. A. L. Pelsers, D. Van Der Voort, P. W. Tang, H. K. Lam, et al. 2005. Rapid analysis of fatty acid-binding proteins with immunosensors and immunotests for early monitoring of tissue injury. Biosens. Bioelectron. 20(12): 2566-2580.

Chan, C. P., M. Lehmann, I. Renneberg, J. Ziegler, W. H. Cautherley, J. F. Glatz, and R. Renneberg. 2006. A novel credit-card style assay for beside determination of fatty acid-binding protein. IVD Technology Magazine 12: 51.

De Groot, M. J., A. M. Muijtjens, and M. L. Simoons. 2001. Assessment of coronary reperfusion in patients with myocardial infarction fatty using acid-binding protein concentrations in plasma. Heart 85(3): 278-285.

Domanovits, H., M. Schillinger, and M. Paulis. 2002. Acute chest pain-a stepwise approach, the challenge of the correct clinical diagnosis. Resuscitation 55: 9-16.

Ecollan, P., J. P. Collet, G. Boon, M. L. Tanguy, M. L. Fievet, R. Haas, N. Bertho, S. Siami, J. C. Hubert, P. Coriat, and G. Montalescot. 2007. Pre-hospital detection of acute myocardial infarction with ultra-rapid human fatty acid-binding protein (H-FABP) immunoassay. Int. J. Cardiol. 119(3): 349-54.

Fransen, E. J., J. G. Maessen, W. T. Hermens, J. F. Glantz, and W. A. Buurman. 2000. Perioperative myocardial tissue injury and the release of inflammatory mediators in coronary artery bypass graft patients. Cardiovasc. Res. 45: 853-859.

Ghani, F., A. H. Wu, L. Graff, C. Petry, G. Armstrong, F. Prigent, and M. Brown. 2000. Role of heart-type fatty acid-binding protein in early detection of acute myocardial infarction. Clin. Chem. 46: 718-719.

Glatz, J. F., B. Haastrup, and W. T. Hermens. 1997. Fatty acid-binding protein and the early detection of acute myocardial infarction: The EUROCARDI multicenter trial. Circulation 96(suppl.): 1-215.

Glatz, J. F., D. Van der Voort, and W. T. Hermens. 2002. Fatty acid-binding protein as the earliest available plasma marker of acute myocardial injury. J. Clin. Ligand. Assay. 25: $167-177$.

Gorski, J., W. T. Hermens, and J. Borawski. 1997. Increased fatty acid-binding protein concentration in plasma of patients with chronic renal failure. Clin. Chem. 43: 193-195.

Leung, W. M., C. P. Chan, M. F. Leung, and R. Renneberg. 2005. Novel "digial-style" rapid test simultaneously detecting heart attack and predicting cardiovascular disease risk. Anal. Lett. 38: 423-429.

Nakata, T. 2003. Human heart-type fatty acid-binding protein as an early diagnostic and prognostic marker in acute coronary syndrome. Cardiology 99: 96-104.

Okamoto, F., K. Sohmiya, Y. Ohkaru, K. Kawamura, K. Asayama, H. Kimura, S. Nishimura, H. Ishii, N. Sunahara, and T. Tanaka. 2000. Human heart-type cytoplasmic fatty acid-binding protein (H-FABP) for the diagnosis of acute myocardial infarction. Clinical evaluation of H-FABP in comparison with myoglobin and creatine kinase isoenzyme MB. Clin. Chem. Lab. Med. 38: 231-238.

Pelsers, M. M., W. T. Hermens, and J. F. Glatz. 2005. Fatty acid-binding proteins as plasma markers of tissue injury. Clin. Chim. Acta 352: 15-35.

Yuan, Y., A. W. Kwong, W. A. Kaptein, C. Fong, M. Tse, J. F. Glatz, C. P. Chan, and R. Renneberg. 2003. The responses of fatty acid-binding protein and creatine kinase to acute and chronic exercise in junior rowers. Res. Q Exerc. Sport 74: 277-283. 